\title{
Lipid Profile in Subclinical and Overt Hypothyroidism
}

\author{
Dr.A.Akila.,DCH.,MD ${ }^{1}$, Dr.V.Usha Padmini.MD ${ }^{2}$, Dr.C.Vignesh ${ }^{3}$, \\ ${ }^{1}$ Assistant Professor, Department of General Medicine, Coimbatore Medical College \&Hospital. \\ ${ }^{2}$ Assistant Professor, Department of General Medicine, Coimbatore Medical College \&Hospital. \\ ${ }^{3}$ post Graduate In General Medicine, Department Of General Medicine, Coimbatore \\ Medical College \& Hospital.
}

\begin{abstract}
The effect of hypothyroidism on lipid metabolism is notable.Both synthesis and degradation of lipid are depressed, the latter especially so,the net effect being one of lipid accumulation.The decrease in lipid degradation may reflect a decrease in postheparin lipolytic activity as well as decrease delivery of lipid to degrading site.Although an increase in serum cholesterol is the most common abnormality of hypothyroidism,serum phospholipid and serum triglycerides are also increased and reverse happens with high density lipoprotein.Plasma free fatty acid is decreased and metabolism of free fatty acid is also impaired.These changes occur only in primary hypothyroidism, not in pituitary hypothyroidism.
\end{abstract}

\section{Introduction}

The following study is about the abnormalities of Lipid metabolism in subclinical and overt hypothyroidism patients. The study and study group and control group were taken in Coimbatore Medical College \& Hospital with inclusion and exclusion criteria.

\section{Aim Of The Study \\ To Find Out}

1. Prevalence of dyslipidemia in hypothyroidism

2.Lipid profile in overt hypothyroidism

3.Lipid profile in subclinical hypothyroidism.

4.Total cholesterol-HDL ratio and LDL-HDL ratio in both overt and subclinical hypothyroidism

\section{Subjects}

\section{Case Selection}

Patients for this were selected from medical out patient \& in patient department of Coimbatore Medical College and Hospital,Coimbatore. 20 patients with TSH levels more than $20 \mu \mathrm{IU} / \mathrm{ml}$ and decreased T4 levels, and another 20 patients with TSH levels between $6 \mu \mathrm{IU} / \mathrm{ml}$ and $15 \mu \mathrm{IU} / \mathrm{ml}$, and T4 levels with in normal range were selected as two study groups. 10 age matched controls were selected from Medicine outpatient department,Coimbatore Medical College \& Hospital,Coimbatore. Control and study groups were screened for markers of hyperlipidemia.

Exclusion : Patients with other risk factors for dyslipidemia like diabetes mellitus, alcohol intake, liver diseases, renal diseases, history of smoking or drug intake like $\beta$ blockers, diuretics,steroids,contraceptive pills were excluded.

Patients with history of acute illness,recent myocardial infarction,recent cerebrovascular accident or recent history of stress were excluded from study. Patients on drugs like lithium, iodide, phenytoin, tolbutamide, steroids, amiodarone and antithyroid drugs were excluded from study.

All the patients in study group were newly detected cases of hypothyroidism. All the newly detected patients were not given thyroxine replacement till the blood samples were being collected.

Methods: In the patients following investigations were done 
1.Urine analysis for albumin,sugar and deposits

2.Blood for

a)Complete hemogram

b)Blood sugar -fasting and post prandial

c)Blood urea

d)Serum creatinine and electrolytes

e)Serum TSH,T4,T3,

f)Serum lipid profile including

-Total cholesterol

-Serum HDL

-Serum TGL

3.ECG

4.X ray Chest $-\mathrm{PA}$ view

\section{Total Cholesterol}

\section{Data Analysis}

Hypercholesterolemia seen in $50 \%$ of patients with overt hypothyroidism and $40 \%$ of patients with subclinical hypothyroidism.

Mean total cholesterol in overt hypothyroidism $235.3 \mathrm{mg} / \mathrm{dl}$.

Mean total cholesterol in subclinical hypothyroidism $202.9 \mathrm{mg} / \mathrm{dl}$

Mean total cholesterol in control group hypothyroidism $166.7 \mathrm{mg} / \mathrm{dl}$

\section{LDL Cholesterol}

$30 \%$ of patients with overt hypothyroidism and $25 \%$ of patients with subclinical hypothyroidism had high LDL-C levels.

Mean LDL cholesterol in overt hypothyroidism $145.4 \mathrm{mg} / \mathrm{dl}$

Mean LDL cholesterol in subclinical hypothyroidism $134.6 \mathrm{mg} / \mathrm{dl}$

Mean LDL cholesterol in control group hypothyroidism $100.4 \mathrm{mg} / \mathrm{dl}$

\section{HDL Cholesterol}

HDL-C less than $35 \mathrm{mg} / \mathrm{dl}$ seen in $30 \%$ of patients in both overt and subclinical hypothyroidism.

Mean HDL cholesterol in overt hypothyroidism $46.5 \mathrm{mg} / \mathrm{dl}$

Mean HDL cholesterol in subclinical hypothyroidism $41.5 \mathrm{mg} / \mathrm{dl}$

Mean HDL cholesterol in control group hypothyroidism $44.3 \mathrm{mg} / \mathrm{dl}$

Mean HDL-C level is higher in overt hypothyroidism and lesser in subclinical hypothyroidism when compared with controls.

Total Cholesterol -HDL ratio TC/HDL $>5$.

$40 \%$ of patients with overt hypothyroidism and $35 \%$ of patients with subclinical hypothyroidism had

Mean TC/HDL cholesterol in overt hypothyroidism 5.1

Mean TC/HDL cholesterol in subclinical hypothyroidism 4.9

Mean TC/HDL cholesterol in control group hypothyroidism 3.7

\section{Triglycerides}

Hypertriglyceridemia seen in $25 \%$ of patients with overt hypothyroidism and $15 \%$ of patients with subclinical hypothyroidism.

Mean Triglyceride cholesterol in overt hypothyroidism $166.3 \mathrm{mg} / \mathrm{dl}$ Mean Triglyceride cholesterol in subclinical hypothyroidism $134.9 \mathrm{mg} / \mathrm{dl}$

Mean Triglyceride cholesterol in control group hypothyroidism $111 \mathrm{mg} / \mathrm{dl}$ 


\section{Ldl-Hdl Ratio}

$40 \%$ of patients with overt hypothyroidism and $30 \%$ of patients with subclinical hypothyroidism had LDL/HDL >3.6. Mean LDL/HDL cholesterol in overt hypothyroidism 3.3

Mean LDL/HDL cholesterol in subclinical hypothyroidism 3.2

Mean LDL/HDL cholesterol in control group hypothyroidism 2.2

Mean Values Of Subfractions Of Lipid Profile In Overt Hypothyroidism

\begin{tabular}{|c|c|c|c|c|c|c|}
\hline Lipid profile & $\begin{array}{l}\text { Control } \\
\text { Sample size }\end{array}$ & $\begin{array}{l}\text { Control } \\
\mathrm{X} \pm \mathrm{SD}\end{array}$ & $\begin{array}{l}\text { Overt } \\
\text { Sample size }\end{array}$ & $\begin{array}{l}\text { Overt } \\
\mathrm{X} \pm \mathrm{SD}\end{array}$ & T-value & P-value \\
\hline Total cholesterol & 10 & $\begin{array}{l}166.7 \pm \\
37.78\end{array}$ & 20 & $\begin{array}{l}235.3 \pm \\
97.4\end{array}$ & 2.1295 & $\begin{array}{l}\mathrm{P}<0.05 \\
(\mathrm{~S})\end{array}$ \\
\hline TGL & 10 & $\begin{array}{l}111 \pm \\
52.05\end{array}$ & 20 & $\begin{array}{l}166.3 \pm \\
70.7\end{array}$ & 2.1863 & $\begin{array}{l}\mathrm{P}<0.05 \\
(\mathrm{~S})\end{array}$ \\
\hline LDL & 10 & $\begin{array}{l}100.4 \pm \\
35.21\end{array}$ & 20 & $\begin{array}{l}145.4 \pm \\
61.08\end{array}$ & 2.14580 & $\begin{array}{l}\mathrm{P}<0.05 \\
(\mathrm{~S})\end{array}$ \\
\hline HDL & 10 & $\begin{array}{l}44.3 \pm \\
7.15\end{array}$ & 20 & $\begin{array}{l}46.5 \pm \\
16.05\end{array}$ & 0.4106 & N.S \\
\hline VLDL & 10 & $\begin{array}{l}22 \pm \\
10.42\end{array}$ & 20 & $\begin{array}{l}33.2 \pm \\
14.21\end{array}$ & 2.2142 & $\begin{array}{l}\mathrm{P}<0.05 \\
(\mathrm{~S})\end{array}$ \\
\hline TC/HDL & 10 & $\begin{array}{l}3.752 \pm \\
0.487\end{array}$ & 20 & $\begin{array}{l}5.115 \pm \\
1.87\end{array}$ & 2.2481 & $\begin{array}{l}\mathrm{P}<0.05 \\
(\mathrm{~S})\end{array}$ \\
\hline LDL/HDL & 10 & $\begin{array}{l}2.239 \pm \\
5.45\end{array}$ & 20 & $\begin{array}{l}3.34 \pm \\
1.75\end{array}$ & 1.9275 & $\begin{array}{l}\mathrm{P}<0.05 \\
(\mathrm{~S})\end{array}$ \\
\hline
\end{tabular}

Mean Values Of Subfractions Of Lipid Profile In Subclinical Hypothyroidism

\begin{tabular}{|c|c|c|c|c|c|c|}
\hline Lipid profile & $\begin{array}{l}\text { Control } \\
\text { Sample } \\
\text { size }\end{array}$ & $\begin{array}{l}\text { Control } \\
\mathrm{X} \pm \mathrm{SD}\end{array}$ & $\begin{array}{l}\text { Overt } \\
\text { Sample size }\end{array}$ & $\begin{array}{l}\text { Overt } \\
\mathrm{X} \pm \mathrm{SD}\end{array}$ & T-value & P-value \\
\hline Total cholesterol & 10 & $\begin{array}{l}166.7 \pm \\
37.78\end{array}$ & 20 & $\begin{array}{l}202.85 \pm \\
63.17\end{array}$ & 1.658 & N.S \\
\hline TGL & 10 & $\begin{array}{l}111 \pm \\
52.05\end{array}$ & 20 & $\begin{array}{l}134.85 \pm \\
91.34\end{array}$ & 0.7617 & N.S \\
\hline LDL & 10 & $\begin{array}{l}100.4 \pm \\
35.21\end{array}$ & 20 & $\begin{array}{l}134.6 \pm \\
54.74\end{array}$ & 1.7901 & N.S \\
\hline HDL & 10 & $\begin{array}{l}44.3 \pm \\
7.15\end{array}$ & 20 & $\begin{array}{l}41.45 \pm \\
10.06\end{array}$ & 0.7971 & N.S \\
\hline VLDL & 10 & $\begin{array}{l}22 \pm \\
10.42\end{array}$ & 20 & $\begin{array}{l}26.9 \pm \\
22.2\end{array}$ & 0.7704 & N.S \\
\hline TC/HDL & 10 & $\begin{array}{l}3.752 \pm \\
0.487\end{array}$ & 20 & $\begin{array}{l}4.92 \pm \\
1.33\end{array}$ & 2.6683 & $\begin{array}{l}\mathrm{P}<0.05 \\
(\mathrm{~S})\end{array}$ \\
\hline LDL/HDL & 10 & $\begin{array}{l}2.239 \pm \\
5.45\end{array}$ & 20 & $\begin{array}{l}3.262 \pm \\
1.07\end{array}$ & 2.8269 & $\begin{array}{l}\mathrm{P}<0.05 \\
(\mathrm{~S})\end{array}$ \\
\hline
\end{tabular}

\section{Conclusion}

1.The prevalence of hypercholesterolemia in hypothyroidism is between $45 \%$ to $60 \%$.

2. Total cholesterol,LDL cholesterol and triglycerides are elevated in both overt and subclinical hypothyroidism.

3.HDL cholesterol showed variable responses.

4.Total cholesterol-HDL ratio and LDL-HDL ratio are higher in both overt and subclinical hypothyroidism.

5.Both overt and subclinical hypothyroidism predispose to early atherosclerosis.

6.In all cases of dyslipidemia,this easily treatable cause should be evaluated eventhough the subject is clinically normal.

\section{Bibliography}

[1]. David A.Warre Timothy M.Cox John.D.Seventh Oxford Text Book of Medicine.

[2]. Williams text book of endocrinology 465-66,1136-W39 
[3]. Harpers Illustrated Biochemistry $28^{\text {th }}$ edition.

[4]. Review of Medical physiology; Ganong $21^{\text {st }}$ edition 2003;328-329

[5]. Text book of Endocrinology -Degroot.753-765.

[6]. Endocrinology and metabolism. Philip Feliq and John Baster-926

[7]. API textbook of Medicine.

[8]. Robert-C Smallridge- Post graduate Medicine.

[9]. Arem and Escalanate-Advances in Internal Medicine vol.41

[10]. Parle et al.Clinical endocrinology 1992,37:411-414.

[11]. Kung and Pang, Clinical endocrinology 1995,43:445-449.

[12]. Killman and Bekker;The Netherlands JI.of clinical endocrinology and metabolism 2000 vol.85,No.5.

[13]. TheoDiekman, Pierre and Demacker.JI.of clinical Endocrinology and metabolism 2000 Vol.83,No.5.

[14]. TheoDiekman,Peter.J.Lansberg.Arch.Of Internal Medicine-1995.July 24,Vol.155.

[15]. anis et al.The Netherlands.Clinical Endocrinology 1996.44 (643-649) 